\title{
The Practice of Belief
}

\section{Prayer and Belief}

In the modern West, religions are commonly conceived of as belief systems. This understanding of religion is modeled on Christianity, particularly Protestantism. As a definition of religion, it is problematic, for instance, in that it postulates that institutionalized religious beliefs form coherent systems and that believing is central to all religions (Asad 2012, 40-42, 47; Beckford 2003, 20; McGuire 2008, 20-24, 39-41). Moreover, it also takes the concept of belief for granted. As anthropologist Malcolm Ruel (2005, 26o263) has shown, the term "belief" involves many Christian connotations that are difficult to shed, including the notions that belief is an interior state, that belief explains behavior, and that belief as such is more important than the object of believing. These connotations make belief a controversial concept within the study of religions (see Cassaniti 2012; Day 2011, 4-27, 191; Stringer 2008, 39-40).

The word "belief" (usko) was not a part of my interview frame. However, the women mentioned it occasionally, in contexts that corresponded with conventional Christian uses of the word. They spoke of belief to convey their acceptance of particular Christian doctrines; moreover, they also made use of it to signal trust and conviction, expressing "belief in" rather than "belief that" (see Ruel 2005, 246). That is to say, they focused mostly on believing over the object of belief - a usage that conforms to Ruel's $(2005,262)$ point about the priority given to belief as such in Christianity.

Helena: Well, what do you think, what could it (deification) mean in the life of an ordinary Orthodox or an ordinary person? What could it involve? How does one strive for it?

Ilmi: Well, you just have to really really believe in everything... what you do in prayer and in the fast. And observe all church instructions. And believe all the time in the things you do.

Ilmi's answer to my question illustrates the women's general emphasis on the act of believing. In the account, moreover, Ilmi also connects belief with practice. She seems to consider belief a state of mind that accompanies pious prayer and other customs. In this chapter, I analyze belief as part of the

(C) HELENA KUPARI, 2016 | DOI 10.1163/9789004326743_008

This is an open access chapter distributed under the terms of the CC-BY-NC License 
women's religious practice. However, my take on belief views it as a property of habitus, not a psychological quality.

One approach towards belief within social sciences has been to focus on belief-in-action. According to this approach, belief is produced through and performed in practices which instill particular orientations towards the world in the bodies of participants (Day 2011, 9-15, 193-196; Mitchell and Mitchell 2008, 80-85). Pierre Bourdieu's outline of practical belief forms one such account of belief. For Bourdieu (1990b, 67-68), belief is a precondition of any investment in any field. It is a "state of the body" that involves an instinctive recognition of the game played in a particular field. It results from a history of participation in the field, and receives its fullest form when the relationship between the individual and the field is characterized by doxa. Speaking of the religious field, Bourdieu also distinguishes between belief in the field and belief as a field-specific practice. Investment in the religious field, he specifies, is not the same thing as "religious faith in the ordinary sense," meaning belief as promoted by religious institutions (Bourdieu 2010, 2-3; Bourdieu 1991a, 20; see also Wood and Altglas 2010, 15).

In what follows, I analyze the women's accounts revolving around two propositions central to Christian doctrine: the existence of God and life after death. However, in keeping with Bourdieu's distinction described above, my focus is more on the women's practical belief than on their "religious faith." In this vein, I consider their accounts to be expressions of belief as a disposition of their habitus. Moreover, I also view them as evidence of how the women's past and present doing of religion has produced and continues to produce belief, through shaping their dispositions concerning the supernatural. I begin by analyzing the women's descriptions of their relationship with God.

God was by far the most often mentioned religious entity in the interviews. This is partly explained by my interview frame; I asked the women one question in which I mentioned God. However, God was also the entity they most often brought up spontaneously. The informants spoke of God approximately twice as often as Jesus and Jesus about twice as often as the Mother of God. The Holy Spirit and the Holy Trinity were mentioned only a few times in the whole material.

Incidentally, given the relatively central status of the Mother of God in Orthodox Christian theology (e.g., Atanassova 2011; FitzGerald 2001, 232-237), and in the lived religion of Orthodox and Catholic lay women as reported in previous ethnographic research (e.g., Dubisch 1995, 230-240; Gemzöe 2000, 53-96; Orsi 2005, 48-72; Vuola 2012), it is surprising that the women of my study did not mention her more often in the interviews. One possible explanation for this is that my Lutheran background affected their readiness to talk about Mary, particularly since I did not specifically encourage them to do so. 
Alternatively, the women's relative neglect of Mary can also be a reflection of the overall Lutheranization of their religion. The role of Mary in Lutheranism is, after all, much less prominent than in Orthodoxy.

Whatever the reason for Mary's minor role in the interviews, the women's accounts clearly designated God as the most important religious entity in their lives. God was inherent to their understanding of the world; in addition, God was also the entity with whom they primarily sought contact and whose presence they most often experienced. The women mainly spoke of God as the all-powerful, all-seeing Creator of the world and as the loving Father of the humankind. A few of them mentioned that in their childhood God was also seen as a punishing force, should you cross Him. The interviewees did not seem to subscribe to this view personally, however. Instead, many stressed the forgiving aspect of God.

On the whole, the women's relationship with God hinged on an experience of being dependent on God: needing God and trusting in His support. Often, they addressed this topic spontaneously and in passing - evidently considering it such a self-evident part of their lives that it did not require any clarification. Some women mentioned that their need for God was especially great during difficult times, whereas others noted that God was necessary in their everyday lives as well. The interviewees conveyed, moreover, that they depended on God for strength, support, and safety. Sinikka, for example, stated: "If I hadn't trusted God, I'd have had it so hard. Since I'm divorced and all. I've received so much help. And God has guided me so well. I can't not believe [in Him]."

It was not uncommon for the women to be emotional in acknowledging their dependence on God. Anna was one of the interviewees who spoke of God with great affection: "I've said, now I feel like crying (sobs), (...) that God has always helped me, through sorrows and tears. He has always helped me. Without God's help I wouldn't have been able to carry on." Such emotional accounts tell of the salience of the experience of God in the lives of the women. They reveal the deep-seated and intimate nature of the interviewees' knowledge of God (see Bourdieu 2001, 38; Scheer 2012, 204-209; Stringer 2008, 63-64, 66). Overall, the interviewees' accounts of their relationship with God can be seen to convey a state of practical belief. For them, the existence of God was not about arbitrary adherence to a set of doctrines; it was something they knew and felt in their bodies (Bourdieu 199ob, 67-68). In other words, the women's particular way of being in the world presupposed the existence of a loving God. He was part of their habitus.

The informants often traced the origin of their dependence on God back to their childhood. Their parents and grandparents, the women noted, had constantly asked God for help in their everyday lives, encouraging their children 
to do the same. I agree that the women's relationship with God was founded on their primary socialization into religion, as is with the formation of habitus more generally. Nevertheless, their reliance on God was also continually fueled by their religious practice. As part of their socialization, the informants had learned concrete, embodied skills for interacting with God and asking for His help (see Asad 1993, 76-77; Bell 1992, 79-81; Bourdieu 1977, 124). Even at present, their sense of practice regularly called forth the use of these skills, and every successful instance reinforced their underlying practical belief in God.

The most important skill through which the women acted out and reinforced their relationship with God was prayer. ${ }^{1}$ They had daily prayer routines; furthermore, they also tended to respond to different exceptional circumstances with prayer. Many explained how their practice of praying intensified at times of hardship: how they prayed in front of the icon, on their knees, using a prayer book, or together with family members or a priest. In their prayers, the women commonly asked for guidance, protection, and help for themselves and their loved ones. In their accounts, they also emphasized the "power of prayer," thus conveying that through praying they often enough attained the relief they were asking for.

Generally speaking, religious worldviews are characterized by the notion that the universe contains other entities besides humans capable of agentic action: deities, demons, angels, spirits, and so on (Riesebrodt 2010, 74-75). In relation to human beings, these non-human agents can take the role of helpers or adversaries. They can contribute positively to the agency of the individual, or hinder and subvert his or her actions (see e.g., Lindhardt 2010, 247-251; Utriainen 2014, 241-243; Weaver 2011, 397, 408-409). Sometimes, non-empirical agents are understood as the ultimate carriers of agentic responsibility instead of the acting individual. This is the case, for example, in such interpretations of the monotheistic traditions that consider God as the originator of all human accomplishments.

Recently, several scholars inquiring into the agency of religious women in monotheistic traditions have considered the notion, present within these traditions, that individuals' capacities to act in the world are produced through submission to God (see also Chryssavgis 2008, 152-154; Harrison 2008, 82). From this perspective, agency involves placing limits on one's possibilities

1 Most public prayer in the Orthodox Church is addressed to Jesus or the Trinity. Orthodox teaching also encourages individuals to pray to the Mother of God, saints, and angels, and to ask for their intercessions. However, God as the Father represents the ultimate recipient of all prayers (Bobrinskoy 2008, 51-54; McGuckin 2011d, 248; Ware 1964, 258-261). The women of my study commonly named the addressee of their prayers as simply "God." 
for action (Bilge 2010, 20-21; Hollywood 2004; Mahmood 2005, 148). However, leaning on empirical data these scholars have illustrated that discipline and obedience can also result in relatively empowered actions with respect to the surrounding social world (Bracke 2008, 63; Mack 2003, 155-157; Orsi 1996, 189-190). The evacuee Karelian Orthodox women, as I have established here, conceived of God as the most powerful agent within the social universe. In their accounts, they emphasized their dependence on God. They saw God as an important influence behind their overall capacities for action, their "energy to act in the world" (Mack 2003, 156). Moreover, the women felt that through acknowledging their dependence on God and asking for His help they received critical leverage with respect to their lives. For them, praying was collaboration with God accomplished through submission. In other words, it was an agentic capacity facilitated by the women's practical belief.

\section{Narrating God's Guidance}

The one question explicitly mentioning God that I asked the women in the interviews was: What situations make you feel that you are in the presence of God or the holy? In their responses, the women often highlighted the Orthodox Divine Liturgy as such a situation. Other answers included, for example, participating in Easter celebrations and visiting graves and monasteries. However, according to the interviewees, God also manifested in nature and in their own lives. In fact, when spontaneously describing their experiences of God, they usually recounted incidents taking place within the context of everyday life.

An experience of the benevolent presence of God could sometimes overtake the women in their daily lives. Commonly, these experiences coincided with situations in which they felt satisfaction over the course their lives had taken. Katri, for instance, answered my question about the presence of God by explaining: "For instance, at the summer cottage on a beautiful day, you may suddenly realize that everything is well just at that moment." And Toini reflected: "When you feel that your prayer has been answered. When you've prayed and hoped so much for something, and then you notice that 'oh, there it was.' Then you know. If only you remembered to give thanks! (...) Oh, there has been so much guidance and such [in my life]."

All in all, the women interpreted various felicitous happenings from over the years as manifestations of God's influence over their lives. Moreover, some of them also described specific, extraordinary incidents of divine intervention. One woman, for example, explained how her severely ill child had regained 
consciousness after she had asked a priest to administer the mystery of the anointing of the sick on her behalf; she spoke of this as a miracle. ${ }^{2}$ Another informant, for her part, spoke of how her child had regained the ability to walk after an accident. She credited this recovery to the Mother of God, to whom she had been praying. Both narratives show the women's experience of God's potential in a particularly clear light: the difference between God's influence and the lack of it could mean the difference between life and death for a loved one. In addition, the accounts also testify to the power of prayer within the women's worldview. After all, they involved the women turning to God and the Mother of God, asking their help with the problem at hand.

In the material as a whole, narratives of such special recoveries or near escapes were rare. Nevertheless, it is not necessarily the case that the women who spoke about such things were the only ones to have faced them. For one thing, I did not ask the interviewees directly about such incidents; those who described them did so spontaneously. Moreover, it also became clear to me during the process that not all the informants were comfortable with discussing highly intimate and emotional topics in their interviews. Some of them wanted, instead, to stick to relatively neutral themes. They were not inclined to share with me their personal experiences of divine intervention - at least not of their own accord, over the limited span of a single meeting.

Besides happy events, the women's lives had included sorrows as well. God, they commonly maintained, had also guided them through various difficulties: deaths, losses, divorces, and so on. Some of these negative events, however, had originally made them feel angry towards God. Elvi, for instance, stated, of the untimely death of her husband: "Man commands and God ordains. That's the truth. (...) I was so bitter, when [my husband] died. (...) But now I've calmly thought that maybe it was better for him [to die] than to remain here seriously ill. He was released from suffering pains." The account is an example of how the interviewees made an effort to accommodate even bad experiences to their idea of a benevolent God. It shows them wrestling with the problem of theodicy.

When coming to grips with her husband's death, Elvi found comfort in the idea of the omnipotence of God: "It's not up to man. It's not up to your actions. There's a greater force which orders the pace of your life. Of course, you can pray and such ... try to help someone or yourself through prayer. I find this idea liberating somehow." Elvi was not the only interviewee who described

2 The anointing of the sick is one of the sacraments of the Orthodox Church, designated to heal a person from both spiritual and physical ailments through prayers and anointing with oil (Arseni 1999, 243-244; see also Melling 1999). 
the realization of one's own powerlessness in relation to God as a liberating experience. Moreover, Elvi's remark concerning prayer is also significant as it indicates that she was quite aware that praying did not always work: God did not answer all prayers. In any case, praying constituted an active attempt to make a difference. It gave Elvi some means of managing situations that were ultimately beyond her control. In other interviews, too, praying came across as a capacity for action that could help the women navigate experiences of ambivalence and disappointment without damage to their belief.

The personal themes and the chronological progress of the interview outline gave the interviews an autobiographical overtone. In their accounts, the women took stock of various episodes of their lives. Often, they pieced together parts of their life stories leaning on the idea of divine guidance. Looking at different events and life phases, they saw evidence of God's influence and even miracles. The interviewees also mostly interpreted negative events as manifestations of God's agency. This religious reading that the women gave their lives made it possible to incorporate even unfortunate experiences into one's overall life story: to give pain and suffering significance.

In his classic research on the autobiographical narratives of Finns, JejaPekka Roos $(1987,64-68)$ notes that their overall tone is determined by an inner experience of life management. The existence of some feeling of control over one's life commonly gives these narratives a positive ring, whereas the lack of such a feeling accompanies more pessimistic interpretations. From this perspective, the Orthodox women's ability to make sense even of negative life events appears crucially important to their general outlook towards life. Their ability to accept different hardships as God's will constituted an important coping mechanism at their disposal, a capacity provided by their embodied adherence to an idea of God.

According to scholar of religion Courtney Bender (2007, 214), religious experience and its interpretation are not separate "but tied together in complex relation to each other, and to the embodied cultural and social worlds in which they are experienced and expressed." That is to say, both experience and the interpretation of experience are mediated by the dispositions of habitus. Moreover, due to the intertwinement of experience and expression, the recounting of a religious experience often serves to reinforce the experience, and the underlying dispositions. The informants' accounts concerning their experiences of God's influence over their lives cited pan-Christian discourses. Christian manners of speaking oriented the women's terminology, which contained concepts like "guidance," "blessing," and "miracle." Nevertheless, their practices of speaking about their experiences of God were also a reflection of their habitus. Furthermore, these practices of speaking constituted 
"performative belief rituals," processes through which the women reinforced their practical belief in God (Day 2011, 110-114).

One effect of post-Reformation religious discourses on social scientific theories of religion is the emphasis on Christianity as a religion of transcendence, characterized by the absence of the supernatural from the world. However, anthropologists of religion Jon and Hildi Mitchell $(2008,87,91)$ argue that practice-oriented notions of belief, which focus on the performative production of religious knowledge through concrete activities, make it possible to investigate the immanence of the non-empirical in Christianity. The accounts discussed here make evident that, for the women of my study, a central experience of the presence of God concerned God's impact in one's life: both in specific events and in the overall course one's life had taken. The women spontaneously interpreted various life events as manifestations of God's presence and guidance. With this interpretative activity, they also continuously reproduced their embodied knowledge of God's presence and guidance.

\section{The Ethics of "Remembering God"}

The displaced Karelian Orthodox women did not promote an idea of religion as a systematic project of cultivating piety. In fact, they rarely even used the term "piety" (hartaus, hurskaus) in connection with their own religious lives. For the women, Orthodoxy seemed to be more about "being" than "becoming": it was as much about not drifting further away from God as it was about moving closer to God. In their religious activities, the interviewees thus aimed for stability rather than change. Nevertheless, in their accounts, some of the women also explicitly acknowledged that religious practices were a means of cultivating one's relationship with God, and that for this purpose they could be undertaken as more of a conscious activity. ${ }^{3}$

Modern secular society was one of the topics that sometimes spurred the women into conveying their opinions on the effects of religious activity. The interviewees reflected on how, in today's world, the pull of earthly

3 Orthodox thought recognizes the formative influence of practice on embodied human subjectivity. In the Orthodox Church, the observation of concrete customs is seen as an important aspect of a religious way of life. Many theologians emphasize worship as the primary channel of Orthodox religiosity (e.g., Conomos 2011, 243; Ware 1964, 271). Moreover, ascetic practices such as prayer and fasting constitute an essential feature of Orthodox piety, and are considered methods of approaching God (Chryssavgis 2008, 160-162; Steenberg 2011). 
attractions was strong. Often, they described religious practices as a much needed counterbalance to secular pastimes, and as a way to develop the spiritual dimension in one's life. In this vein, Lempi stated: "Sometimes I feel that this fussing about and all the daily chores and superficial hobbies take too much space. (...) I have this aspiration that I could get a bit deeper. That I wouldn't only scratch the surface." And Kirsti explained: "I feel a great need to, it's not a habit but I feel that I've got to get to go to church and to the Liturgy. (...) At this age I feel that I get so much out of it. I have to go there to remedy myself, to be fixed up, let's put it this way."

An interesting detail in Kirsti's account is that she explicitly denies that her need to go to church regularly could be described as a habit. On occasion, also the other women voiced opinions distancing their activities from routine practice. For instance, while making the sign of the cross was often described as a habitual custom in the material as a whole, not all interviewees were satisfied with this description. They stressed that the sign consists of a mental dimension as well. Lempi, for example, stated: “I wouldn't say that you need to reflect on making the sign of the cross every time. But I don't like for it to be done negligently, in passing; it's not that kind of a thing. (...) In a way [you need] to know that it's not just any kind of symbol. Because it's simultaneously a credo. You don't cross yourself if you don't believe at all."

In this account, Lempi defends the sign of the cross against common-sense understandings of rituals and routines as void of significance. She emphasizes thatalthoughthesign of thecrossisabodilygestureitisnotamechanicalformality. The account can also be viewed as a reaction against those negative interpretations of Orthodox Christianity that consider it a ceremony-centered religion (muotomenot, muotokirkko) in contrast with belief-oriented Lutheranism. This was one of the critiques often raised against the Orthodox faith in the post-war period (Kananen 2010, 73-74).

The crux of Lempi's account is that the practice of making the sign of the cross should be observed with a proper frame of mind. It should be accompanied by belief. This opinion is similar to Ilmi's reflection (quoted in the beginning of this chapter) about the importance of "really believing" in what one is doing in order to do it properly. Both women's accounts replicate the common Christian understanding that belief forms the ground of pious behavior (Ruel 2005,261 ). Outlines that posit a unidirectional relationship between belief and practice, however, remain blind to the generative aspect of practice: to practice as productive of belief (Bourdieu 199ob, 69; Bourdieu 1977, 79-80; see also Bell 1992, 82, 87, 108-109).

In their interviews, the women did not speak of religious practice explicitly as productive of belief. However, they did mention effects that particular 
customs had on their bodies. They spoke, for instance, of the "nurturing" influence of the Divine Liturgy or the "warmth" of home icons. In addition, to describe the generative aspects of daily religious activity, one interviewee employed an idiom that lends itself very well to my analysis. Although this expression did not circulate widely in the material, it describes the women's general views on religious practice well. Therefore, it is worthy of closer scrutiny. The expression is that of "remembering God."

When I interviewed Kirsti she was in her early sixties, a farm mistress from Ilomantsi, the easternmost town of present-day Finland. The farm was her childhood home, which she and her husband had taken over when her parents retired. Kirsti's childhood had coincided with the first post-war decade. At the time, the family's Orthodoxy had not been particularly featured. For instance, as a child Kirsti had never seen her parents make the sign of the cross. "Maybe it was because they had to become so Finnish," she stated. Nevertheless, Orthodoxy had been passed on to Kirsti and her siblings as an unquestioned worldview, which included such principles as respect for God, life, and one's elders.

In adulthood, Kirsti had embraced many of the religious customs that her parents had given up. A particularly active period in her religious practice ensued when her two youngest children were born and baptized into Orthodoxy. "I had the courage to teach them [Orthodox] religion," Kirsti said as she reflected on the change in the status of Orthodoxy between her own childhood and that of her children. Nevertheless, even when describing her current religiosity, she prioritized her frame of mind over rigorous practice:

Praying is the hardest thing in the world. It's the hardest thing. And, if I'm being honest, often what happens is that depending on the things that are burning in your life you may need God sometimes more and sometimes less. And if $\mathrm{He}$ is farther away, you don't pray so actively. (...) Although you do remember God every day, He comes up in different ways. However, nothing is more difficult than taking up and following regular prayers, in the mornings and evenings. It requires an immense amount of self-discipline. Remembering God and small prayers, they are easy, but... Sometimes, the only thing I do is make the sign of the cross.

In her interview, Kirsti spoke repeatedly about "remembering God." On the one hand, she stated that daily religious habits had the effect of bringing God to mind. Icons, for instance, acted as reminders of religion during busy everyday 
life: "[Icons] have a very important function in that, if a person does not have the time to pray or to practice piety much, glancing at them reminds you of these things." On the other hand, she also repeatedly stressed that recalling God did not necessarily have to include elaborate rituals: "It's a part of everyday life, and in your haste, you don't have to get into a rut, to stop and to pose, then make the sign of the cross. The mere attitude, remembering God with love, crossing oneself somewhere like [when] you pass [an icon]; to my mind it's also a moment that touches eternity." Raili, among others, spoke of the same thing, noting how every time she passed by her icons she "thought of religion." In their accounts, both women implied that seeing icons helped them to cultivate the proper religious state of mind in the course of their daily lives.

Kirsti's and Raili's accounts are good illustrations of the small "acts of recognition" that, according to Bourdieu (199ob, 67-68), constitute and sustain practical belief. When the women noticed an icon, they intuitively and immediately identified various cultural significations pertaining to it, which in turn reinforced their embodied adherence to this underlying symbolic system. In the interviewees' everyday lives, countless similar acts of recognition took place; as one of them remarked, "anything" could remind you of God. However, the example of icons alone sufficiently establishes why I consider the idiom of "remembering God" such a happy one. Religious practice per se, as well as encounters with artifacts, symbols, environments, and situations that the women's bodies recognized as religious, made them remember God. They renewed the women's investment in the religious game and their practical belief in God as its central element.

The expression of "remembering God," however, does not only describe what ideally happened in the course of religious practice. In Kirsti's parlance, "remembering God" also referred to a disposition that involved thinking about God in a loving manner. According to Kirsti, it was important to remember God in one's actions and everyday life. ${ }^{4}$ This normative usage of the idiom captures the women's general idea of the proper Orthodox Christian outlook on life, to which every believer should aim. It depicts a religious mindset that should govern everyday life but can also be put aside, forgotten, in which case the spiritual dimension of life is in danger of slipping from focus.

4 In the Finnish language, remembering (muistaminen) signifies, besides recollection, active deeds with which one shows consideration for another person (Grönfors 2006, 250). This connotation is present also in Kirsti's use of the expression "remembering God." Moreover, the concept is present also in the Bible, for instance, in the well-known verse from Ecclesiastes (12:1) which begins: "Remember your Creator in the days of your youth." 
Whereas, of all the informants, only Kirsti explicitly spoke of the importance of "remembering God," other women also alluded to similar notions of piety. As I have previously established, to speak of remembering was a central way in which the interviewees approached the theme of intentional practice. Thus, they stressed the importance of remembering to observe particular customs: to pray, give thanks to God, quiet down on Sundays, light candles for deceased relatives, and so on. The emphasis on remembering, in a sense, was their way of speaking of religious practice as an ethical activity. On the whole, in their accounts, the women did not view religion as a project with change as its goal. Only a few of them even mentioned the possibility of methodical cultivation of piety - only to marvel, alongside Kirsti, at the amount of selfdiscipline such conscious devotions must require. The interviewees' own goal was, rather, to maintain a steady religious mindset. This ideal of stability is present in their focus on remembering to practice, and is aptly represented by the expression "remembering God."

So far in this chapter, I have produced a rather straightforward picture of how the interviewees' practical belief in God was constituted. My argument has been that practices have the capacity to produce subjects that subscribe to the message inherent in the practices: performing the sign of the cross, for instance, constitutes the individual as a believer (Asad 1993, 76-77; Bell 1992, 100; Bourdieu 199ob, 67-68). However, Lisa Adkins, among others, has criticized Bourdieuan social theory for its tendency to assume that incorporation (for example, in the form of such acts of recognition that I have discussed here) always works. Adkins (2003, 37) stresses that, since habitus is produced in interactions with multiple social environments, it does not fit effortlessly to any one of them. This causes ambivalence within practice.

Scholar of religion Catherine Bell (1992, 207-209) speaks of the social structuring that happens in ritual activities as a negotiated appropriation. The participant, she remarks, brings to practice his or her whole history of experiences, by virtue of which he or she comes to seize the symbolic order reconstituted in practice, and to shape it into a personal and provisional understanding of the social world. According to Bell, ritualized practices actually tolerate a lot of internal heterodoxy and even resistance from the part of participants who commonly do not need to verbalize their views of what the ritual is about. On the basis of Adkins' and Bell's remarks, it is important to acknowledge that my discussion leaves open the evacuee Karelian Orthodox women's particular personal understandings of the social world constituted through their religious activities. The specifics of their views on God and the social world are not attainable through my analysis, and are certain to contain an amount of variation. 
I end this section by making note of some of the women's spontaneous reflections concerning the topic of religious practice not working properly. Above, I took up Lempi's account in which she noted that she did not like for the sign of the cross to be done "negligently, in passing." A few other women also made parallel remarks in their interviews. Vieno, for example, stated that it is not right to make the sign of the cross for show: "It can't be that [one makes the sign of the cross thinking] 'now I show how I make the sign of the cross, look at me.' It's a gesture to bless the food and to bless yourself." In their accounts, both Lempi and Vieno imply that the sign of the cross is not always made with the right state of mind, with proper belief. Simultaneously, they reveal their awareness that practice is not always what it seems: that external uniformity can mask heterogeneous motives as well as dissimulation. The talk of negligent routines and inauthentic customs can be understood as the women's way of engaging with the issue of the ambivalence of practice, and the question of what constitutes authentic religious practice in the first place.

\section{Performing Life after Death}

Old age does not bring about radical changes in religiosity. Existing research suggests that the one factor that most effectively predicts religiosity in old age is childhood socialization into religion (Dillon and Wink 2003, 181-183). It is not uncommon for religious activity to increase in old age, but this increase is often connected with practical matters such as free time gained after retirement, not with newfound interest in religion as such (Dillon 2007, 531-534; Hunt 2002, 78-79). Religion had also become more significant to the displaced Karelian Orthodox women as they had aged. Usually, they explained the escalation of their religious activity with reference to the quieting down of their lives. Alternatively, the women could also give to understand that their present-day lives were afflicted by feelings of frailty and powerlessness that also contributed to the growing importance of religion. In this vein, previous research has shown that religion can help those who are already religious in coping with age-related anxieties and sorrows (Dillon and Wink 2003, 185-187; McFadden 1996, 167-168).

The women reported the ardency of their praying having increased as they had gotten older. At the time of the interviews, the women prayed first and foremost for the well-being of their children and grandchildren. They often stressed that, at present, an important way for them to affect the lives of their loved ones was through prayer. Toini, for instance, stated: "I've thought that I have to pray [for my children and grandchildren] so much beforehand that it 
will carry them even after my death." Praying, moreover, was seen as a special duty of old people. In fact, the women seemed to give a religious significance to grandmotherhood far more openly and often than to motherhood. Whereas motherhood was described through the practical aspects of caretaking, in accounts of grandmotherhood these responsibilities gave way to the spiritual task of protecting family members through prayer.

A second major concern in the women's prayers was their health. The informants prayed for increasing health, or that their health would, at least, not deteriorate further. Furthermore, some of them specifically asked for a good death. For example, Esteri, who had many health problems, spoke of her hopes for the future: "[I pray that] God would give me strength for as long as I live. That I could remain just as I am, old. You can't help it if you get sick for a long time, you can only pray. (...) I hope that the Heavenly Father won't leave me in bed for a long time. That'd be so hard for the family." As the excerpt shows, even when speaking of her health Esteri was concerned for her family, hoping that the process of her dying would not be too burdensome for them.

Otherwise, the interviewees also emphasized how their praying was very much about giving thanks to God. The women were thanking God for answering their prayers and for their share in life. Siiri, for instance, reflected: "I'm at that age now that I've begun to give thanks for everything that is. When I go on my walks, they're all about morning prayer, as I walk in the mornings. They're discussions with God. And I've noticed that I rarely ask for anything, I just give thanks." All in all, the contents of the women's prayers reflected their concerns and priorities at the time of the interviews. They were concerned about their loved ones, wondering what would happen to them after the women had died. They needed God's help due to their own health problems, and worried about how their mortal lives would end. In addition, they were looking backward at their lives, wanting to thank God for all that they had received from Him. Thus, in a good part of their prayers, the women seemed to process the issue of their approaching deaths.

Especially in the earliest interviews, death was a difficult topic for me to approach. I had included the theme in the interview frame, but found it hard to bring it up, fearing the women's reactions. Soon, however, I realized that it was me, and not the informants, for whom death and loss were terrifying subjects. Many of the women, in fact, took up the topic on their own, speaking at length on various issues related to death. Particularly the older interviewees spoke of their own deaths as being already quite close at hand. Moreover, the women also recounted deaths of loved ones from over the years. Some related detailed accounts of deaths that had been particularly affecting, whereas others lamented in a more general way how so many around them had died. 
Elsa, for instance, noted: "It makes you feel so bad when they go, one after the other, to the bosom of the earth, and there's no one left." The women might also spontaneously recount to me premonitions that they had received, in the form of dreams, visions, and scents, concerning the death of a loved one, often a parent or grandparent.

Nevertheless, the women also made clear their belief in death not being the end. According to Christian doctrine, Jesus died on the cross so that man would be redeemed from death; this teaching had not been lost on the women. On the contrary, many of them mentioned the crucifixion and resurrection of Jesus, or the "Easter message," as a cornerstone of the Orthodox faith. Often, they took up the Christian promise of life after death when considering their own approaching deaths. Furthermore, the idea of an afterlife was also reflected in the way in which the women spoke of their deceased relatives. Dead loved ones were warmly described as, for instance, being "at the home of the Heavenly Father" or "in the other world," or looking at the women "from above." A few interviewees even told of their experiences of being in contact with departed relatives, usually through dreams.

The issue of how death was regarded in pre-war Karelia was spontaneously taken up by many women who spoke with approving tones of how, in their childhood homes, death was accepted as part of life, not pushed out of sight. It was common for them to note how this way - the "Karelian" or the "Orthodox" way - of relating to death emphasized continued connection with the deceased. The informants could, for instance, remember how as children they had gone to visit graves with their grandmother, bringing with them food for the dead. ${ }^{5}$ Through these remarks, they described the environment in and the practices through which their dispositions regarding death had originally been formed. A lot had changed between their childhood and today. However, even in their present-day lives the women engaged in many customs through which they cultivated their belief in life continuing after death.

To begin with, the interviewees often explained that Orthodox funeral rites regard death with a focus on the continuance of existence, and how this creates an undertone of hope and brightness that characterizes the Orthodox "culture of death" as a whole (see also Hamalis 2011a). Siiri, for instance, noted:

5 Kalmoilla käyminen was an ethnic Karelian Orthodox ritual in which the deceased was remembered by bringing food to his or her grave, for him or her to eat, although the food was often subsequently distributed to the poor (Keinänen 2014, 30-36; Stark 2002, 66-68, 142-146). It was still operative in inter-World War Border Karelia, but waned away rapidly in post-war Finland, due to old family graves being out of reach and negative reactions from the part of the locals (Makkonen 1989, 218-223, 251-252). 
"[An Orthodox funeral] is such a comforting ceremony. It's so comforting, it doesn't make death hard to grasp." Moreover, the women also described the various customs that they observed to remember their deceased loved-ones. They lit candles for their dead as part of every church visit, attended Liturgies to honor the dead on special memorial days of the Church, and organized panikhida services held in the memory of a particular family member. Martta, for example, explained: "Every time I go to church, I light wax candles to them (deceased relatives), and remember them. And ask them for relief in life." 6 In addition, the women also remembered their dead by visiting grave sites, and by burning candles at home. Tarja listed the days: "I always remember my husband's day of death, mother's day of death, their burial days ... Father's birthday. But I seem to have forgotten his burial date. Or, I'm not quite sure ... Anyhow, if I remember, I always light a candle for them [on those days]."

In their commemorative customs, the interviewees also employed Orthodox traditions to remember Lutheran relatives. This suggests that when the women targeted particular people with religious practices, their non-Orthodoxy was not a hindering factor. Some of them, however, actually took up this issue in their accounts. Esteri, for instance, explained: "I always remember to light a wax candle at the days of death and birth. You have to remember the Orthodox during their days of death. (...) You can even remember those who weren't Orthodox." Remarks such as this are yet another example of how the women managed the existence of two religious affiliations within their families. These accounts show awareness of difference, yet conclude that, when it came to remembrance, this difference was ultimately meaningless.

Sometimes, the women mentioned that they had already taken care of various practical issues in preparation for their own deaths. They might have acquired a gravesite from a particular cemetery, making sure that they were satisfied with the spot that will one day host their remains. In particular, the women wanted to ensure that their graves would be visited - that they would be remembered like they had remembered those who had already passed away. Other preparatory measures included deciding what was to be written on the gravestone, as well as choosing a burial outfit and the icon that was to be placed in the coffin with them. All in all, the interviewees spoke of making

6 According to Orthodox teaching, the living and the dead are part of the same community of believers (Ware 1964, 258-259). This notion is manifested in the practice of praying both to and for the departed. Nevertheless, Martta's description also echoes the ethnic Karelian conception of the dead as agents that can be asked for help with all kinds of endeavors (Stark 2002, 140-142). In Orthodox prayer, the deceased are not asked for relief directly; they are asked for intercessions (Nyström 2001, 18-19). 
concrete arrangements regarding one's death as one example of the practical and accepting attitude towards death that they had learned during childhood.

At the time of the interviews, the displaced Karelian Orthodox women were, on average, 75 years old. In the interviews, many of them reported how their practices of praying and remembering the departed had intensified in recent years, in response to their ailing health and the growing number of deaths around them. The women, it seems, had taken to managing illness and death through methods familiar to them, practices their habitus instinctively recognized and was geared to respond to. This familiarity also ensured the comforting function of these practices in the lives of the women. The women's observance of these customs, however, was not merely reactive in nature. For one thing, the practices can also be understood to constitute "performatives of age" (see Vakimo 2001, 36-38). Contemporary social gerontological scholarship emphasizes the socially constructed nature of all conceptualizations of age. Viewed from this perspective, the interviewees' activities related to the dead and to their grandchildren were actions through which they constructed and acted out their identity as old women, "grannies." Furthermore, through the same practices the interviewees also continuously generated their practical belief in life after death, and in God's guidance in the face of death. The women's belief in life after death was concretely actualized in customs that established a connection with deceased loved ones. It was this experience of a sustained connection that, to them, testified to the continuance of life.

In fact, the women often seemed to treat the interview situation itself as an opportunity to work on their belief. Although death was not a prominent theme in the interview frame, many of the women made it more so by taking up the issue spontaneously. Commonly, their anecdotes and reflections concerning death constituted performances of belief through which they reinforced their trust in life after death. Nevertheless, I do not mean to suggest that the women did not harbor any qualms concerning death. Certainly, the material does not contain accounts in which the interviewees doubted Orthodox teachings concerning death. However, their non-existence can also reflect the women's reluctance to express such opinions to me. Overall, what I argue is that, through observing customs and producing interview accounts that hinged on the idea of life after death, the informants cemented their belief in this notion, in spite of the doubts they might also harbor.

All in all, the analysis above demonstrates how the women's habitus, as a believing habitus, expanded their capacity to act in the world beyond limits difficult to surpass with other means. Praying was a way to influence the lives of loved ones even when they were beyond the women's more concrete aid - as in the case, for instance, of grown-up children. Moreover, through 
commemorative practices the women took care of and kept in touch with deceased relatives, transcending the barrier separating the living from the dead. Both customs, in this sense, significantly enhanced the informants' agentic capacities, facilitating their coping with feelings of powerlessness caused by events like children leaving home, illness, and death. Thus, they are a good example of how the women's embodied adherence to the Orthodox symbolic system contributed to their understanding of agency. 